\title{
METHODS OF CHECKING THE RELIABILITY OF SOFTWARE APPLICATIONS IN THE AVIONIC SYSTEMS INTEGRATED ALONG THE DIGITAL DATABUS MIL-1553B
}

\author{
METODY TESTOWANIA NIEZAWODNOŚCI \\ APLIKACJI OPROGRAMOWANIA W SYSTEMACH \\ AWIONICZNYCH ZINTEGROWANYCH NA BAZIE \\ CYFROWEJ SZYNY DANYCH MIL-1553B
}

\author{
Sławomir Michalak, Andrzej Szelmanowski, Andrzej Cieślik \\ Air Force Institute of Technology \\ Instytut Techniczny Wojsk Lotniczych \\ 01-494 Warszawa ul. Księcia Bolesława 6
}

slawomir.michalak@itwl.pl, andrzej.szelmanowski@itwl.pl, andrzej.cieslik@itwl.pl

\begin{abstract}
This The paper presents results of research that was carried out in the Air Force Institute of Technology (ITWL) with respect to test whether information in the avionic systems integrated along the digital databus MIL-1553B is processed correctly. The second part goes into details related to methods that are used in the ITWL to test the MIL-1553B databus on the stages when start up and validation of an integrated avionic system are carried out, in particular those that were applied for upgrading of aircrafts operated by the Air Forces of the Republic of Poland.
\end{abstract}

Keywords: integrated avionic systems, research methods

Streszczenie: W artykule przedstawiono wyniki badań przeprowadzonych w Instytucie Technicznym Wojsk Lotniczych (ITWL) w zakresie metod testowania poprawności przetwarzania informacji w systemach awionicznych zintegrowanych na bazie cyfrowej szyny danych MIL-1553B. Omówiono metody testowania szyny MIL-1553B stosowane $\mathrm{w}$ ITWL na etapie uruchamiania $\mathrm{i}$ walidacji zintegrowanego systemu awionicznego $\mathrm{w}$ ramach prac związanych $\mathrm{z}$ modernizacją awioniki statków powietrznych wykorzystywanych w Siłach Zbrojnych RP.

Slowa kluczowe: zintegrowane systemy awioniczne, metody badań. 


\section{METHODS OF CHECKING \\ THE RELIABILITY OF SOFTWARE APPLICATIONS IN THE AVIONIC SYSTEMS INTEGRATED ALONG THE DIGITAL DATABUS MIL-1553B}

\section{Introduction}

Contemporary avionic systems (including the systems for navigation, communication, weapon operation and data logging) installed on aircraft boards are commonly integrated by means of the MIL-1553B databus. The standard MIL-STD-1553B is eagerly used due to the available frequencies and modes of operation related to integration of avionic equipment as well as feasibility to guarantee the required redundancy of information that is obtained from specific devices. For instance, architecture of the hybrid navigation system called STARTUS (fig. 1) can serve here as an example. The system has been integrated by the company Sextant Avionique and is operated on the helicopters of Tigre brand [3].

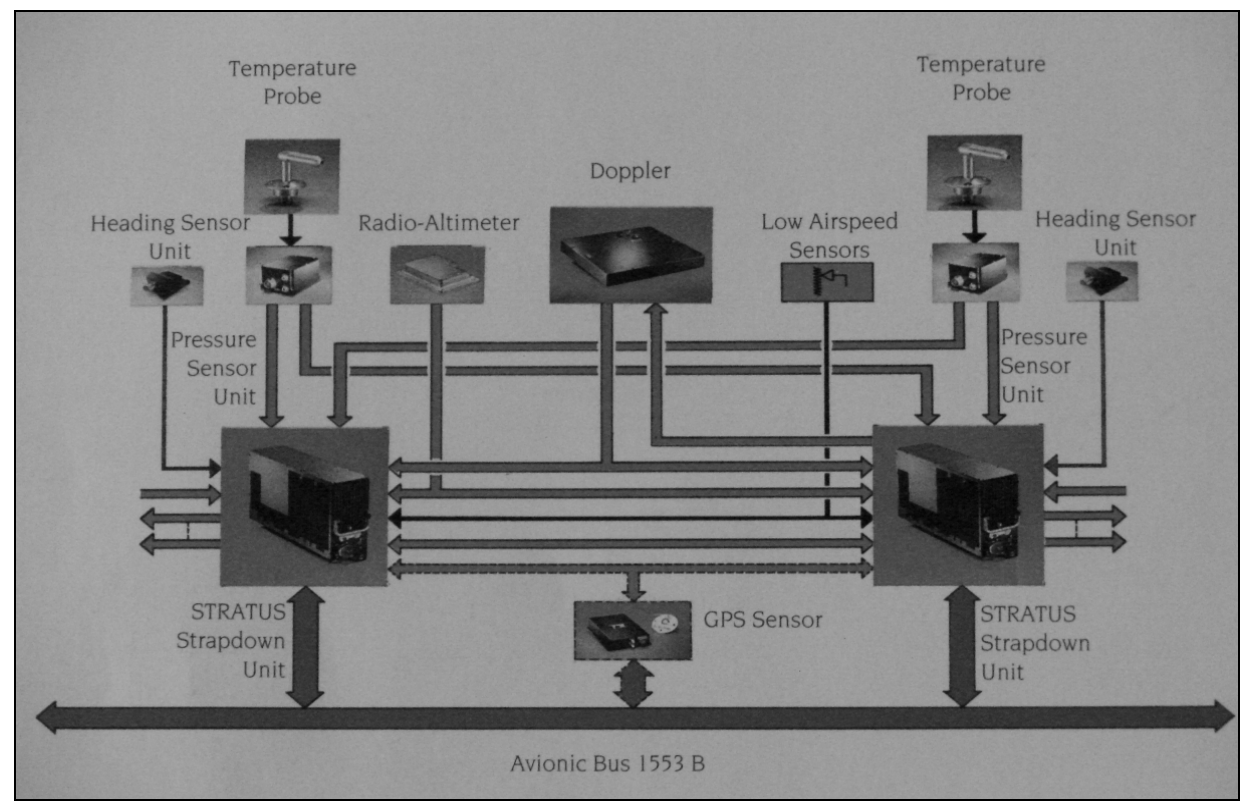

Fig. 1. Typical architecture of the navigation system from Sextant Avionique, the system is integrated with use of the digital databus to MIL-1553B 
The serial databus to MIL-1553B with the transmission rate of $1 \mathrm{Mb} / \mathrm{s}[5,6]$ serves as a basis for integration of avionic navigation systems (MIL-STD1553B) and weapon management (MIL-STD-1760B), but nowadays it is more and more frequently used for integration of the flight control systems, monitoring of the power system and the flight management systems. This is the standard that is widely used as one of basic tools for integration, therefore the MIL-1553B databus was selected for the integrated system developed in ITWL (the integration station and on-board applications).

Every integrated system that conforms to the standard MIL-STD-1553B (fig. 2) typically comprises the following components: bus controller (CPU), remote terminal (remote hub) that integrates individual avionic systems (or a subsystem with a built-in terminal hub as an autonomic remote terminal with its internal interface) and bus monitor (bus log system as an option). The aforementioned components are connected together with use of the following facilities: wiring cables, made up of screened twisted pairs in protecting insulation sheath, coupling transformers (coupling devices that separate the databus from the subsystems to be connected) and separating resistors (to match the line impedance).


Fig. 2. Typical subsystems that co-operate with the MIL-1553B databus (on the left) and components of the MIL-1553B databus (on the right) used for the integration hardware

The bus controller is the major component of the digital databus to MIL1553B. It takes control over entire flow of information during the transmission process with use of the "command/response" method. On the other hand every terminal incorporates its interface, in the form of an electric circuit that is placed into a remote device (or into a subsystem that is directly connected to the databus). Its major task is meant as data transfer to or from the specific subsystem, which is controlled by the bus controller (it can also perform the archiving tasks as an option). 
The MIL-STD-1553B standard deals with two types of interfaces to the databus: direct connection to the bus or connection via coupling transformers. The direct connection is carried out with use of two separating resistors (one resistor for each wire) and a separating transformer. The resistances should be properly adjusted so that the receiver resistance is adequately high (the bus "sees" the interface as "unloaded"). Such an approach reduces possible distortions of the signal down the databus that may be brought in by the terminals attached. However, that type of connection is associated with some drawbacks that include lack of protection against damages if any short-circuits occur down the bus section between the receiver and the bus. As a failure to meet the foregoing prerequisites may result in problems with control or even damages to the bus components, adequate analyses and tests of electric parameters of the bus should be carried out as early as on the design stage.

Major constrains of the bus to MIL-1553B in terms of equipment integration include requirements to the maximum length of the bus wires and values of electric parameters for bus components (including coupling transformers and matching resistors of remote devices) as well as requirements related to protection of the bus against possible damages (minimum impedance of remote terminals /devices and ratings for separating resistors). The MILSTD-1553B defines also requirements to tests of data transmission performance and such diagnostic methods that can be applied with use of more sophisticated measuring instruments.

\section{Standard methods for tests of databuses to MIL-1553B}

According to presumptions of the MIL-STD-1553B document [1,2], standard testing methods applicable to MIL-1553B buses include tests for terminals of the databus to MIL-1553B, however such tests should be carried out on the stage when integrated avionic systems are being designed. Firstly it is necessary to perform tests of remote terminals, then those of the bus controller and finally the entire integrated system must be checked. Requirements to tests of terminals (remote terminals, bus controllers and monitoring units) are subdivided into two major areas: electric tests of interfaces (including tests of the noise impact) and tests of data transmission protocols (depending on terminal types). The tests are intended to verify whether requirements of the standard MIL-STD-1553B are met.

Electric tests of interfaces can be classified to four basic areas: tests of input and output characteristics, tests of electric insulation and tests of noise 
generation and suppression. Tests of input characteristics comprise checking of polarity, measurements of input impedances, signal amplitudes, crossover distortions, rise and fall times of signal pulses, analysis of conditions for mutual suppression and deviation of transmission rates. In addition to the above, tests of output characteristics include also checking whether the established thresholds are exceeded, symmetrical properties of the transmission line and measurements of produced noise. By means of electric insulation tests it is possible to verify the quality of insulation between electric conductors and cable screens. In case of the bus's redundancy (if insulation is also applied between the bus conductors) quality of insulation is defined as a ratio of voltages on active and passive bus conductors. Tests of noise impact are required for evaluation of transmission errors when signals are sent by the terminal at presence of white noise. The noise is produced until the moment when number of words received by a certain terminal exceeds the minimum threshold required by the standard MILSTD-1553B. The test is intended to decrease probability that the transmitted package will be distorted and erroneous status can occur.

Tests of data transmission protocols are intended to check the protocol of a remote terminal and the protocol of the bus controller. Tests of the remote terminal protocol should give the proof that all the responses of the terminal are correct across the entire range of message formats that are transmitted between the bus controller and the terminal as well as between two terminals (including the mode of commands and responses with and without the data word). The transmission formats should be tested with use of all the possible subaddresses and word counters implemented within the specific terminal. In addition, the response time of terminals is checked as well. Correctness of information transmitted by the terminal is checked under specific conditions when variable errors are introduced into the transmitted packages. Examination criteria comprise values for some typical errors, e.g. errors of synchronization, coding, package length (framing), parity and so called "lost frame" errors. In turn, tests of the bus controller protocol need familiarity with the controller software. The first step of the examination is to check whether the bus controller is capable to produce its list of commands and data. Sometimes it is pretty difficult to carry out such a test, particularly for systems where information exchanged via the databus needs to insert variables into the list of commands. Another important issue covered by the test is to monitor whether the bus controller never generates wrong commands or such commands that are prohibited by the system specification and it transmits information from a single bus only. 


\section{Test methods applicable to the MIL-1553B implemented by ITWL}

The major objective assumed by ITWL for testing components of the MIL$1553 \mathrm{~B}$ databus is to determine the operability and performance of all the system components integrated in accordance to the standard MIL-STD1553B. The applicable test procedures must guarantee that the design under test meets requirements of the standard MIL-STD-1553B and the implemented software is capable to properly manage the MIL-1553B databus. Standards components of the MIL-1553B databus (e.g. receivers, encoders, sequencers of protocols, etc.) are nowadays easily available for designers of integrated systems, but it still remains a problem to combine such appliances in a clever way and development of relevant software within the frameworks of the assumed system concept. It is why designers (including ITWL) permanently enhance and improve testing methods based on their own interpretation of the MIL-STD-1553B standard. These methods are intended to prove that both the designs and implemented system configurations derived from that standard can be successfully operated. Testing methods dedicated to the MIL-1553B databus and applied by the ITWL engineers [4] on the stages of commissioning and validation of the integrated avionic system are performed as a part of a wide project related to upgrade of avionic systems of aircrafts that are operated by Polish Air Forces. Special attention is paid to methods that are suitable for verification of the following issues: data visualization, package transmission (transmission protocols), signal conditioning (timings of electric pulses). Testing methods dedicated to timings of electric signals include methodical procedures for measurements of electric parameters attributable to components of the MIL1553B bus and analyses of oscillograms (fig. 3).
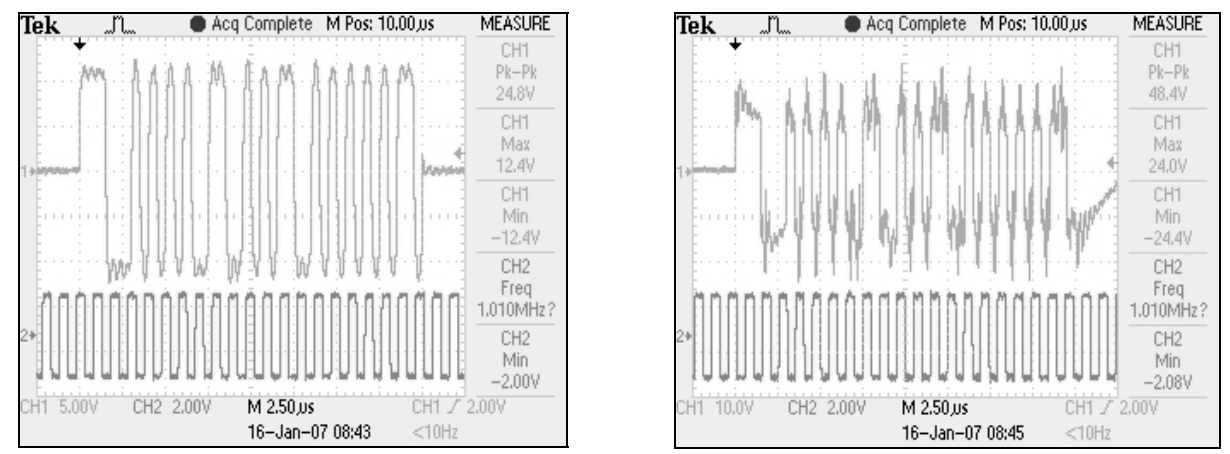

Fig. 3. Correct timings of communication signals (on the left) and distortion of the signals (on the right) caused by unmatched components of the MIL-1553B databus 
The right approach to the integration process (and actually applied by numerous designers) consists in taking advantage of emulation and simulation of components incorporated into the integrated system with use of dedicated software. Such methods are particularly suitable for the bus controller. Emulation is used in order to substitute some hardware avionic subsystems with selected functions thereof (e.g. a bus tester is used instead of a remote terminal for communication tests). On the other hand, simulation is used to check whether the desired system function are correctly executed as a result of the intended application (e.g. for data processing or control operations). Hence, emulation is used for hardware components of the integrated avionic system while simulation - for software that animates the system.

For instance, the PCB module BUS-65517-II along with the dedicated software IDEA (Integrated Development, Emulation and Analysis) is a typical tool that is used in the ITWL for emulation and simulation of components embedded into integrated systems. The PCB is suitable to set up a universal workstation (so called integration arrangement) that can be used for integration of avionic subsystems to the standard MIL-STD-1553B. The module is capable to simultaneously imitate such units as the bus controller, 31 remote terminals and the active monitor of the bus to MIL1553B. In addition, it can be used for testing of transmission protocols as it is furnished with the function to enforce errors during data transmission. Testing methods dedicated to check correctness of transmission protocols and used by the ITWL mainly involve measurements and recording with use of the MIL-1553B bus recorder while selected components of the integrated avionic system are in operation.

In turn, the PCB module of the type BU-65570-I is the basic tool that is used in ITWL for the process of equipment integration within avionic subsystems. The module serves simultaneously as the tester and simulator of databuses to MIL-STD-1553B and it cane be used both on the design stage (concept and development) and for production tests and regular operation of fully configured integrated systems. The PCB firmware has the interactive menu that makes it possible to set up easily all the possible operation modes. Its operation capacities are even enhanced by incorporation of realtime libraries that are made available in the $\mathrm{C}$ language for the Windows NT and XP operating systems. Therefore a HMI interface between users and working procedures can be established and such an interface offers benefits on the stages of testing, simulation and operability proofing of the applications that handle a specific subsystem. 
Validation of the integrated avionic system developed by ITWL involved methods of testing whether data received from individual devices integrated along the MIL-1553B databus are visualized in a correct manner. These methods comprise visual assessment whether the selected functions are selected correctly or not and visual presentation of shapes, colours, names and values of all the presented parameters both under static and dynamic conditions (corresponding to permanently changing flight conditions) when subsequent operation modes of individual subsystems are selected one after another and made involved into mutual collaboration.

All the foregoing methods and tools used to test correctness of the information processing can be used during operation of an integrated avionic system, although testing of visualization accuracy is expected to be performed by direct users (pilots and technical staff) while testing of transmission protocols and timings of electric signals - by representatives of repairing units or designers of systems that are to be integrated with the MIL-1553B databus.

\section{Conclusions}

Fast development of avionic subsystems and associated handing software results in definition of new integration methods and that, in turn, creates the demand for testing. For instance, some parts of the MIL-STD-1553 standard served as a basis to develop new standards, such as MIL-STD-1773 (light pipe buses) and MIL STD-1760B (weapon management). These standards impose new demands for testing of information processing correctness during start-up, commissioning and operation of equipment that is integrated in accordance to the above standards.

The proposed methods are used by ITWL to support the testing process of avionic systems integrated on the MIL-1553B databus during all the stages from start-up and commissioning up to regular operation. These methods cover three levels of testing: quality of the information visualization (level of direct user), transmission of test protocols (level of the maintenance staff) and timing of electric signals (level of the equipment manufacturers). Therefore, they served as a basis for development of the operational simulator of the MIL-1553B databus designed for processing of information from all the on-board avionic system. The constructed simulator can be used for both training and operational purposes 


\section{References}

1. Dokument standaryzujący: Digital Time Division Command/Response Multiplex Data Bus. STANAG 3838 edycja 3.

2. Dokument standaryzujący: Multiplex Application Handbook. MILHDBK-1553:2005.

3. Materiały reklamowe firmy Sextant Avionique: Navigation Systems Laser Gyro Attitude and Navigation Hybrid Inertial Reference System STRATUS. 1997.

4. Michalak S. i inni: Stanowisko integracyjne systemów awionicznych na bazie cyfrowych szyn danych. Sprawozdanie z pracy, BT ITWL, Warszawa, 2004.

5. Norma obronna: Statki powietrzne - Pokładowa szyna danych Wymagania ogólne. NO-16-A202:1998.

6. Norma obronna: Wojskowe statki powietrzne - Pokładowa magistrala danych typu MIL-STD-1553 - Wymagania. NO-16-A202:2007.

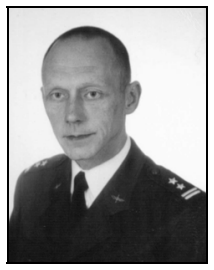

Dr inż. MICHALAK Sławomir, Instytut Techniczny Wojsk Lotniczych, Warszawa, Kierownik Zakładu Awioniki, specjalizacja: systemy nawigacyjne i systemy automatycznego sterowania lotem. Autor kilku prac w tej dziedzinie.

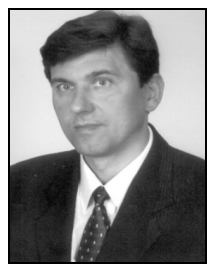

Dr inż. SZELMANOWSKI Andrzej, Instytut Techniczny Wojsk Lotniczych, Warszawa, Adiunkt w Zakładzie Awioniki, specjalizacja: systemy nawigacyjne i systemy automatycznego sterowania lotem. Autor kilku prac $\mathrm{w}$ tej dziedzinie.

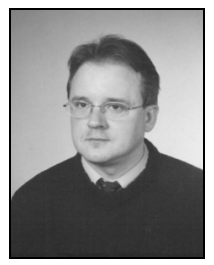

Mgr inż. CIEŚLIK Andrzej, Instytut Techniczny Wojsk Lotniczych, Warszawa, Specjalista w Zakładzie Awioniki, specjalizacja: zintegrowane systemy awioniczne i cyfrowe szyny danych. Autor kilku prac $\mathrm{w}$ tej dziedzinie. 


\section{METODY TESTOWANIA NIEZAWODNOŚCI APLIKACJI OPROGRAMOWANIA W SYSTEMACH AWIONICZNYCH ZINTEGROWANYCH NA BAZIE CYFROWEJ SZYNY DANYCH MIL-1553B}

\section{Wprowadzenie}

Współczesne systemy awioniczne (m.in. nawigacyjne, łączności, uzbrojenia, rejestracji danych) zabudowane na wojskowych statkach powietrznych są integrowane z użyciem szyny MIL-1553B. Standard MILSTD-1553B jest tam powszechnie stosowany $\mathrm{z}$ uwagi na posiadane częstotliwości i tryby pracy $\mathrm{w}$ zakresie integracji urządzeń awionicznych oraz możliwość zapewnienia wymaganej redundancji informacji z nich otrzymywanej. Przykładem może być architektura hybrydowego systemu nawigacyjnego STRATUS (rys. 1), zintegrowanego przez firmę Sextant Avionique i stosowanego m.in. na śmigłowcach Tigre [3].

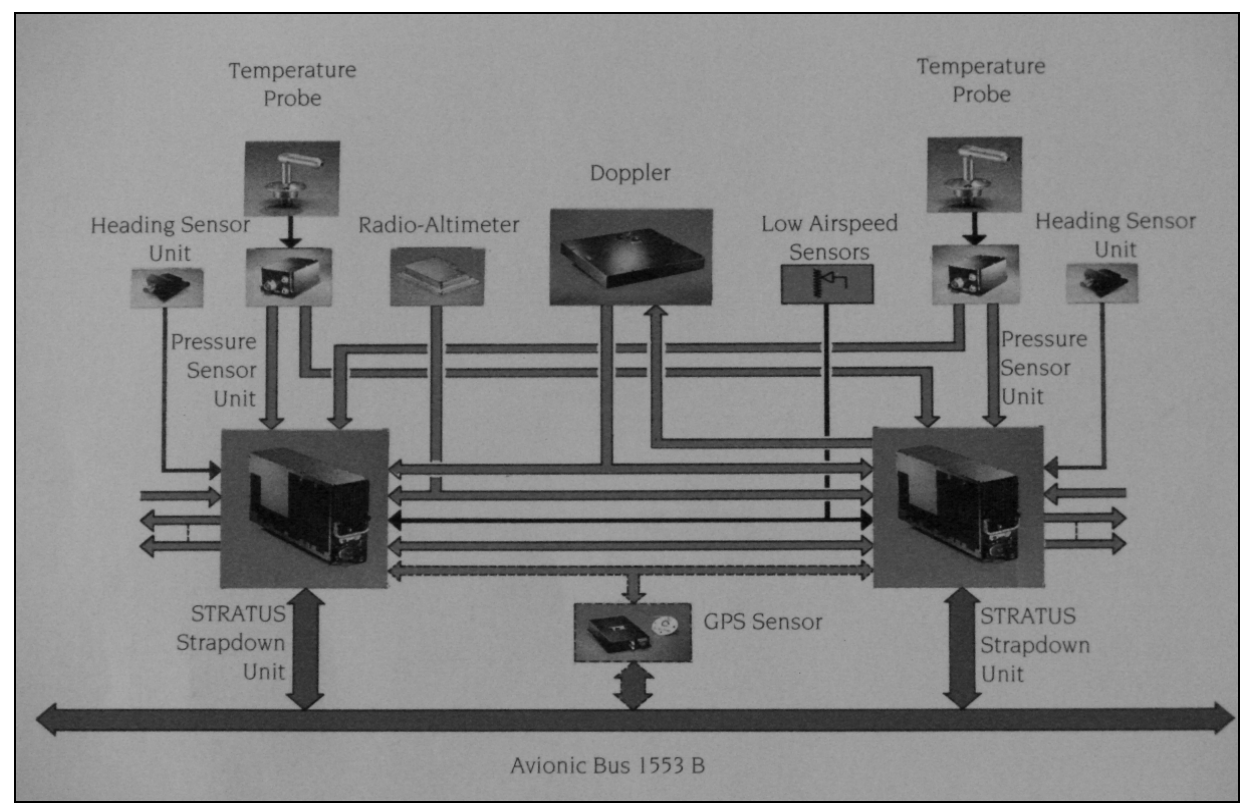

Rys. 1. Przykładowa architektura systemu nawigacyjnego firmy Sextant Avionique, zintegrowanego z użyciem cyfrowej szyny danych MIL-1553B 
Szeregowa szyna MIL-1553B o szybkości transmisji $1 \mathrm{Mb} / \mathrm{s}[5,6]$ jest podstawą integracji awionicznych systemów nawigacyjnych (MIL-STD1553B) i zarządzania uzbrojeniem (MIL-STD-1760B), ale coraz częściej jest ona używana również do integracji systemów w zakresie kontroli lotu, kontroli zespołu napędowego oraz systemów zarządzania lotem. Standard ten stanowi jedno $\mathrm{z}$ podstawowych narzędzi stosowanych obecnie do integracji, dlatego też szyna MIL-1553B została wybrana dla systemu integrowanego w ITWL (stanowisko integracyjne i aplikacje pokładowe).

Typowy system zintegrowany spełniający standard MIL-STD-1553B (rys. 2) zawiera następujące elementy: kontroler szyny (sterownik), odległy terminal (odległe urządzenie końcowe) integrujący poszczególne podsystemy awioniczne (lub podsystem $\mathrm{z}$ wbudowanym urządzeniem końcowym jako autonomiczny odległy terminal $\mathrm{z}$ wewnętrznym interfejsem) oraz monitor szyny (opcjonalnie rejestrator szyny). Elementy łączące powyższe urządzenia to: okablowanie w postaci ekranowanej skrętki pary przewodów umieszczonych $w$ izolacji ochronnej, transformatory sprzęgające (sprzęgacze izolujące szynę od integrowanych podsystemów) oraz rezystory separujące (dopasowujące impedancję).
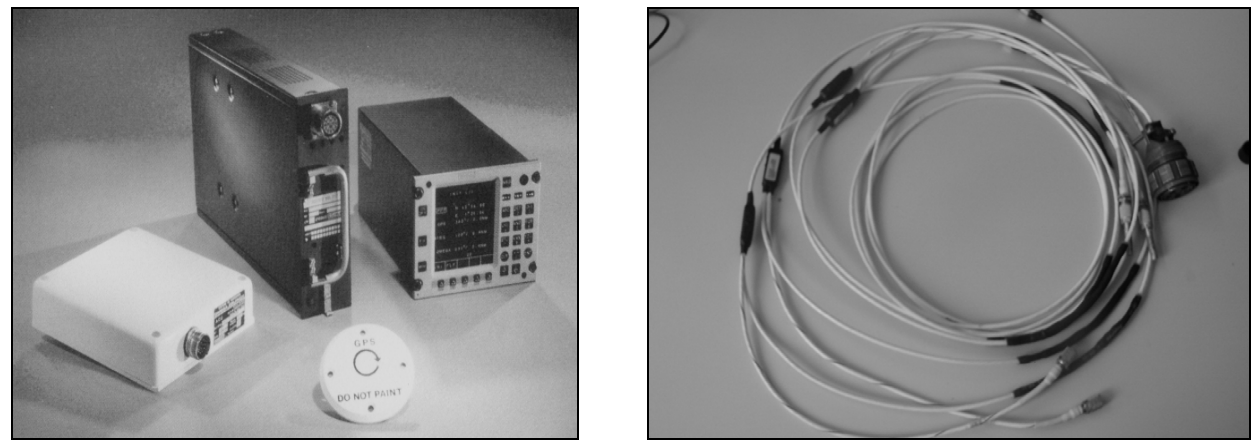

Rys. 2. Przykładowe podsystemy współpracujące z szyną MIL-1553B (po lewej) oraz części składowe szyny MIL-1553B (po prawej) wykorzystywane do integracji

Najważniejszym elementem cyfrowej szyny danych MIL-1553B jest kontroler szyny. Główną jego funkcją jest sterowanie przepływem danych w procesie transmisji przy wykorzystaniu metody typu „rozkaz/odpowiedź”. $\mathrm{Z}$ kolei terminal zawiera interfejs $\mathrm{W}$ postaci obwodu elektrycznego zlokalizowanego w odległym urządzeniu końcowym (lub wewnątrz podsystemu bezpośrednio podłączonego do szyny danych). Jego głównym zadaniem jest transfer danych „do" lub „z" tego podsystemu, sterowanego przez kontroler szyny (opcjonalnie spełnia funkcje archiwizacji). 
Standard MIL-STD-1553B uwzględnia dwa typy interfejsu szyny danych: bezpośrednie podłączenie do szyny oraz podłączenie za pomoca transformatorów sprzęgających. Podłączenie bezpośrednie realizowane jest przez dwa rezystory separujące (po jednym na przewód) oraz transformator izolacyjny. Wartości rezystancji tych rezystorów powinny być tak dobrane, aby impedancja odbiornika była wysoka (szyna „widzi” wtedy interfejs jako „nieobciążony”). Ta technika redukuje ewentualne zniekształcenia sygnału na szynie danych, które powoduje podłączony do niej terminal. Problemem związanym z bezpośrednim podłączeniem odbiorników do szyny jest brak ochrony przed jej uszkodzeniem w przypadku wystapienia zwarcia na odcinku połączenia odbiornika z szyną. Ponieważ niespełnienie powyższych warunków może spowodować problemy ze sterowaniem lub uszkodzeniem elementu szyny, stąd odpowiednie analizy i testy parametrów elektrycznych szyny powinny być prowadzone już na etapie jej projektowania.

Podstawowe ograniczenia szyny MIL-1553B w zakresie integracji urządzeń obejmują wymagania dotyczące dopuszczalnych długości i wartości parametrów elektrycznych przewodów szyny ( $\mathrm{w}$ tym transformatorów sprzęgających i rezystorów dopasowujących urządzenia) oraz wymagania obowiązujące w zakresie zabezpieczenia szyny przed ewentualnymi uszkodzeniami (minimalna impedancja urządzenia końcowego i wartości rezystorów separujących). Standard MIL-STD-1553B określa także wymagania dotyczące testów $\mathrm{w}$ zakresie poprawności transmisji danych oraz metod diagnozowania, których realizacja wymaga zastosowania złożonych narzędzi pomiarowych.

\section{Standardowe metody do testowania szyny MIL-1553B}

Zgodnie z założeniami MIL-STD-1553B [1,2], standardowe metody testowania szyny MIL-1553B obejmują testy terminali szyny danych MIL1553B, które powinny być przeprowadzane już na etapie projektowania zintegrowanych systemów awionicznych. Jako pierwsze powinny być wykonywane testy odległego terminala, następnie testy sterownika szyny, a na koniec całego integrowanego systemu. Wymagania $\mathrm{W}$ zakresie testowania terminali (odległych terminali, kontrolerów szyny i monitorów) są podzielone na dwa główne obszary: elektryczne testy interfejsów (wliczając w to testy wpływu szumu) oraz testy protokołu danych (zależne od typu terminala). Wykorzystywane są one do weryfikacji zakresu spełnienia standardu MIL-STD-1553B. 
Elektryczne testy interfejsu mogą być podzielone na cztery podstawowe zakresy: testy charakterystyk wejścia i wyjścia, izolacji elektrycznej oraz generacji i thumienia szumu. Testy charakterystyk wejścia obejmuja sprawdzenie: biegunowości, impedancji, amplitudy sygnału, zniekształcenia przejścia przez zero, czasu narastania i opadania sygnału, warunków wzajemnego tłumienia oraz stabilności prędkości transmisji. Testy charakterystyk wyjścia obejmują dodatkowo: przekroczenia, symetryczność, poziom generowanego szumu. Za pomocą testów izolacji weryfikuje się jakość izolacji pomiędzy przewodem i ekranem. W przypadku redundancji szyny (dla izolacji pomiędzy przewodami szyny) wymaganie to jest określone jako stosunek pomiędzy napięciem na szynie aktywnej i biernej. Testy wpływu szumu są wymagane do oceny błędu transmisji z terminala $\mathrm{W}$ obecności szumu białego. Szum jest generowany do momentu, aż liczba słów przyjętych przez terminal przekroczy wartość wymaganą przez standard MIL-STD-1553B. Test ten redukuje prawdopodobieństwo wystąpienia ,przekłamanego" statusu transmitowanego słowa.

Testy protokołu obejmują sprawdzenie: protokołu oddalonego terminala i protokołu kontrolera szyny. Testy protokołu oddalonego terminala mają na celu wykazanie, że wszystkie odpowiedzi terminala są poprawne w zakresie transmitowanych formatów pomiędzy kontrolerem szyny a terminalem oraz między terminalami (m.in. tryb rozkazów i odpowiedzi ze słowem danych i bez niego). Formaty te powinny być testowane $\mathrm{z}$ wykorzystaniem wszystkich podadresów oraz liczników słów zaimplementowanych w terminalu. Dodatkowo sprawdzany jest czas odpowiedzi terminala. Sprawdzenie poprawności informacji transmitowanej $\mathrm{z}$ terminala jest badane w warunkach wprowadzania zmiennego błędu. Kryteria sprawdzenia obejmują wartości błędów: synchronizacji, kodowania, długości słowa, parzystości oraz tzw. przerwy $\mathrm{w}$ danych. $\mathrm{Z}$ kolei testy protokołu kontrolera szyny wymagają uprzedniej wiedzy o jego oprogramowaniu. Pierwszym krokiem jest sprawdzenie zdolności kontrolera szyny do generacji listy poleceń i danych. Często jest ono trudne do wykonania, zwłaszcza w systemach, gdzie występujące na szynie wyniki powodują wstawienie zmiennych do listy poleceń. Również ważną częścią tego testu jest monitorowanie, czy kontroler szyny nie generuje nieprawidłowych poleceń lub poleceń zabronionych przez specyfikacje tego systemu oraz czy transmituje on informacje tylko do jednej szyny. 


\section{Metody testowania szyny MIL-1553B wykorzystywane w ITWL}

Podstawowym celem testowania elementów szyny MIL-1553B przyjętym w ITWL jest określenie jakości i zdolności funkcjonowania podsystemów integrowanych według standardu MIL-STD-1553B. Wykorzystywane do weryfikacji procedury testowe maja zapewnić, że sprawdzany projekt odpowiada wymaganiom standardu MIL-STD-1553B i że oprogramowanie zaimplementowane $\mathrm{w}$ zakresie zarządzania szyną MIL-1553B funkcjonuje poprawnie. Standardowe komponenty szyny MIL-1553B (m.in. odbiorniki, kodery/enkodery, sekwencery protokołów itd.) są obecnie powszechnie dostępne dla projektantów systemów zintegrowanych, natomiast problemem jest umiejętne ich „połączenie” i „oprogramowanie” w ramach przyjętej koncepcji systemu. Dlatego też projektanci (w tym ITWL) rozwijaja indywidualne metody testowania, oparte na własnej interpretacji standardu MIL-STD-1553B. Metody te mają udowadniać, że ich projekty i przyjęte konfiguracje systemu zintegrowanego na bazie tego standardu pracuja poprawnie. Wśród metod testowania szyny MIL-1553B, wykorzystywanych w ITWL [4] na etapie uruchamiania i walidacji integrowanego systemu awionicznego $\mathrm{w}$ ramach prac związanych $\mathrm{z}$ modernizacją awioniki statków powietrznych wykorzystywanych w Siłach Zbrojnych RP, szczególne miejsce zajmuja metody testowania poprawności: zobrazowania danych (wizualizacji); pakietów (protokołów kontrolnych); sygnałów (przebiegów impulsów elektrycznych). Metody testowania przebiegów sygnałów elektrycznych obejmują metodyki pomiaru parametrów elektrycznych elementów szyny MIL-1553B oraz analizy oscylogramów (rys. 3) w zakresie poprawności przebiegu impulsów elektrycznych zarejestrowanych na szynie w czasie pracy urządzeń integrowanego systemu awionicznego.
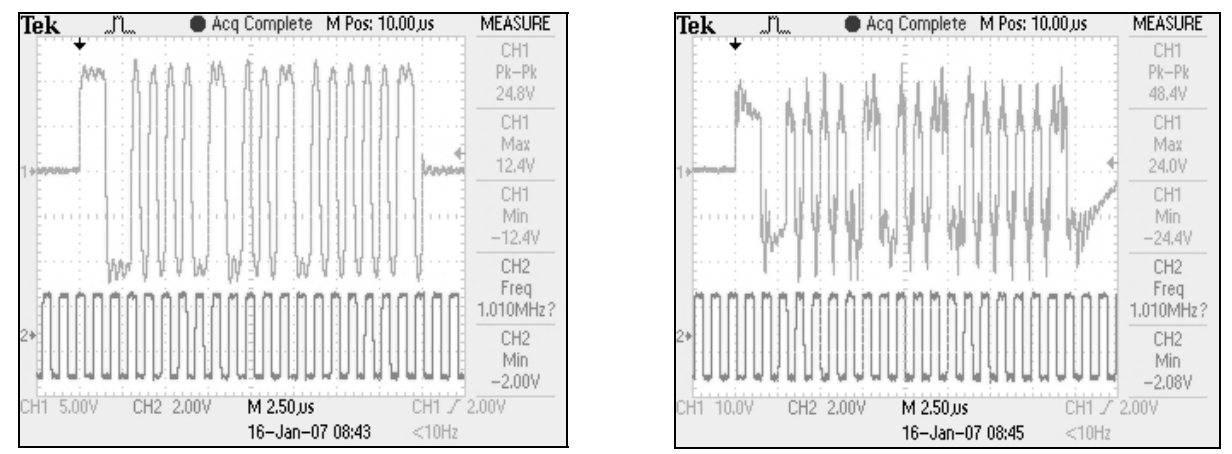

Rys. 3. Poprawne przebiegi sygnału komunikacji (po lewej) i błędy sygnału (po prawej) spowodowane niedopasowaniem elementów szyny MIL-1553B 
Właściwym podejściem $\mathrm{w}$ procesie integracji (stosowanym przez wielu projektantów) jest wykorzystanie tzw. emulacji i symulacji elementów integrowanego systemu $\mathrm{w}$ tworzonym oprogramowaniu, szczególnie $\mathrm{w}$ odniesieniu do kontrolera szyny. Emulacja jest stosowana w celu zastępowania poszczególnych, rzeczywistych podsystemów awionicznych ich wybranymi funkcjami (np. do komunikowania się zamiast oddalonego terminala podsystemu używa się testera szyny). Z kolei symulację wykorzystuje się do sprawdzenia, czy zaplanowane funkcje systemu jako wynik działania opracowanej aplikacji (np. w zakresie przetwarzania danych lub sterowania) realizowane są poprawnie. Emulację zatem stosuje się do urządzeń integrowanego systemu awionicznego, zaś symulację - do oprogramowania obsługującego ten system. Typowym narzędziem stosowanym w ITWL do emulacji i symulacji elementów integrowanego systemu jest karta typu BUS-65517-II z oprogramowaniem IDEA (Integrated Development, Emulation and Analysis). Na jej bazie można zbudować uniwersalną stację roboczą (tzw. stanowisko integracyjne) wykorzystywaną do integracji podsystemów awionicznych według standardu MIL-STD-1553B. Karta ta równocześnie może „modelować” kontroler szyny, 31 oddalonych terminali oraz aktywny monitor szyny MIL1553B. W dodatku, może ona być wykorzystana w procesie testowania protokołów kontrolnych $\mathrm{z}$ uwagi na posiadaną funkcję umożliwiająca wprowadzanie błędów $\mathrm{w}$ transmisji danych. Wśród metod testowania poprawności protokołów kontrolnych wykorzystywanych w ITWL podstawową rolę odgrywają metody ich pomiaru i rejestracji za pomoca rejestratora szyny MIL-1553B w czasie pracy wybranych urządzeń integrowanego systemu awionicznego.

Z kolei podstawowym narzędziem używanym w ITWL w procesie integracji urządzeń podsystemów awionicznych jest karta typu BU-65570-I, stanowiąca jednocześnie tester i symulator szyny według standardu MILSTD-1553B. Może być ona stosowana zarówno na etapie projektowania (koncepcji i rozwoju), jak i podczas testowania w procesie produkcji i eksploatacji końcowej konfiguracji zintegrowanego systemu. Oprogramowanie tej karty posiada interaktywne menu, pozwalające na łatwe ustawianie jej wszystkich trybów pracy. Jego możliwości zostaja zwiększone poprzez dodanie bibliotek czasu rzeczywistego, które są dostępne w języku programowania $\mathrm{C}$ dla systemów operacyjnych Windows NT i XP. Umożliwia to otrzymanie interfejsu pomiędzy użytkownikiem a programem roboczym, który jest wykorzystywany na etapie testowania, symulacji oraz demonstracji działania aplikacji obsługującej dany podsystem. 
W ramach walidacji zintegrowanego systemu awionicznego w ITWL wykorzystuje się metody testowania poprawności zobrazowania danych otrzymanych z poszczególnych urządzeń zintegrowanych na szynie MIL1553B. Obejmuja one oceny wizualne w zakresie poprawności wybierania funkcji oraz zobrazowania kształtów, kolorów, nazw i wartości prezentowanych parametrów zarówno w stanach statycznych, jak i dynamicznych (modelujących zmieniające się warunki lotu) podczas wybierania kolejnych trybów pracy (i współpracy) poszczególnych podsystemów.

Przedstawione wyżej metody i narzędzia testowania poprawności przetwarzania informacji mogą być wykorzystane podczas eksploatacji zintegrowanego systemu awionicznego, przy czym przewiduje się, że testowanie poprawności zobrazowania będzie wykonywane przez bezpośredniego użytkownika (pilota i personel techniczny), natomiast testowanie poprawności protokołów i przebiegów sygnałów elektrycznych przez przedstawicieli zakładów naprawczych lub projektanta systemu zintegrowanego z szyną MIL-1553B.

\section{Podsumowanie}

Rozwój podsystemów awionicznych oraz obsługującego ich oprogramowania prowadzi zarówno do powstawania nowych metod integracji, jak i ich testowania. Dla przykładu, części standardu MIL-STD1553 stanowią podstawę standardu w wersji MIL-STD-1773 (szyny światłowodowe) i MIL STD-1760B (zarządzanie uzbrojeniem). Także i z nimi związane są problemy testowania poprawności przetwarzania informacji w czasie uruchamiania i eksploatacji urządzeń integrowanych $\mathrm{w}$ oparciu o te standardy.

Zaproponowane metody wykorzystywane w ITWL wspomagaja proces testowania poprawności $\mathrm{w}$ czasie uruchamiania i eksploatacji systemów awionicznych integrowanych na szynie MIL-1553B. Metody te obejmują trzy poziomy testowania poprawności: jakości zobrazowania informacji (poziom użytkownika), przesyłanych protokołów kontrolnych (poziom obsługi) oraz przebiegów sygnałów elektrycznych (poziom producenta). Stanowią one podstawę do opracowania dla potrzeb szkoleniowych i eksploatacyjnych tzw. symulatora działania szyny danych MIL-1553B w zakresie przetwarzania informacji z pokładowych systemów awionicznych. 